\title{
Summary of the Internal Pressure Capacity of Prestress Concrete Containment Vessel (PCCV)
}

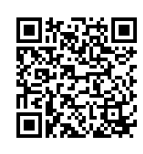

\author{
Chaobi Zhang* and Dianguang Zhang \\ School of Ocean and Civil Engineering, Dalian Ocean University, China
}

Submission: August 28, 2018; Published: October 25, 2018

*Corresponding author: Chaobi Zhang, School of Ocean and Civil Engineering, Dalian Ocean University, China; Tel: +86-411-8476-3248;

Email: zhangchaobi@aliyun.com

\section{Abstract}

Prestressed concrete containment vessel (PCCV) is the unique structures that are constantly exposed to harsh environmental conditions, acts as the final defensive shield against radiation leakage, and ensuring the structural safety of the dome is critical in nuclear power industry. Many related studied about the internal pressure capacity of PCCV are summarized in this paper.

Keywords: Ultimate internal pressure; Prestressed concrete containment vessel; Mechanical analysis, Failure mode; Finite element

\section{Introduction}

The nuclear containment acts as the final barrier against the release of radioactivity. Hence, its design, strict performance and safety evaluation under severe conditions are of great significance, whether through experiments or by numerical methods. In particular, the behavior prediction from functional to structural failure when the internal pressure is higher than the design pressure (Pd) is very important in terms of structural safety.

\section{Experimental Work}

On the one hand, much work has been done experimentally on the safety evaluation of prestressed concrete containment vessel (PCCV) subjected to internal pressure. A 1:4 scale PCCV model has been analyzed by the U.S. nuclear regulatory commission (NRC) and the nuclear power engineering cooperation (NUPEC) of Japan, and it is found that the limit state is firstly detected at 2.5Pd and the final torn failure is at 3.3Pd [1]. Another test in India shows that the crack firstly appears when pressured up to 1.56Pd [2]. In addition, a 1:10 scale model was tested in China and the final failure is at $2.7 \mathrm{Pd}$ with cylinder tendons fractured [3]. Rizkalla [4] tested a 1:14 scale model of PCCV, and the structure displays considerable ductility before hoop tendons reaching tearing failure at the mid-height of the cylinder.

\section{Finite Element Analysis}

On the other hand, various finite element analyses of PCCV have also been reported. Yonezawa et al. [5] established a finite

Table 1: Summary and comparison of related research results. model and predicted the ultimate capacity pressure to be 3.97Pd and the tendons torn at the mid-height of the wall. While Basha et al. [6] predicted it is in a range of 2.95-3.15Pd and the failure is at the local liner of the equipment hatch opening. Prinja et al. $[7,8]$ found that the containment finally fails as the extensive concrete crack at the mid-height of the cylinder. Lee [9] found the crack occurs in all parts of the containment. Kwak \& Kim [10] proposed a modified stress-strain relationship to simulate the post-cracking behavior, and results indicate the structure fails at the mid-height under 3.3Pd. Whereas, another numerical simulation suggests a final failure of vertical crack near the buttress [11]. While Zhou Z [12] found that the hoop tendons near the equipment hatch have yielded and the corresponding concrete has reached the ultimate tension strain.

Results of $\mathrm{Hu}$ [13] show that there are extensive cracks at the dome apex, the ring beam and the cylinder bottom, and the corresponding failure pressure is $1.86 \mathrm{Pd}$. Other researches $[14,15]$ simulated the over-pressurization of the $1: 4$ mode experimentally tested by NRC/NUPEC previously, and the numerical results are consistent with the experiment. Besides, another report shows that the liner integrity has significant effects on the loss of confinement, because the concrete failure appears quite early [16]. Xia et al. [17] sponsored a round robin analysis and predicted that the failure capacity is all above $2.5 \mathrm{Pd}$. Zhang [18] developed an integral constitutive model to study the ultimate internal pressure, and the result is 3.04Pd.

\begin{tabular}{|c|c|c|c|c|c|c|}
\hline \multirow{2}{*}{ References } & \multicolumn{2}{|c|}{ Tendon Yielding } & \multicolumn{2}{c|}{ Extensive Concrete Cracking } & \multicolumn{2}{c|}{ Liner Tear } \\
\cline { 2 - 7 } & Pressure /Pd & Location & Pressure /Pd & Location & Pressure /Pd & Location \\
\hline$[19,17]$ & - & - & 2.5 & A & 3.05 & A \\
\hline$[20]$ & $>2.5$ & - & 2 & B & - \\
\hline
\end{tabular}




\section{Civil Engineering Research Journal}

\begin{tabular}{|c|c|c|c|c|c|c|}
\hline [21] & $>3.35$ & - & 3.35 & A & - & - \\
\hline [5] & 3.97 & A & - & - & - & - \\
\hline$[6]$ & - & - & - & - & $2.95-3.15$ & B \\
\hline$[1,22]^{*}$ & - & - & 2.5 & A & 3.3 & B \\
\hline$[7,8]$ & 3.6 & A & - & - & 2.5 & B \\
\hline [9] & - & - & 2.92 & A & - & - \\
\hline [10] & 3.3 & A & - & - & - & - \\
\hline$[11]$ & 2.78 & A & - & - & - & - \\
\hline$[3]^{*}$ & 2.7 & A & - & - & - & - \\
\hline [23] & 2.86 & $\mathrm{~A}$ & $>2.86$ & - & - & - \\
\hline$[24]$ & $>2.91$ & - & - & - & 2.91 & C \\
\hline$[12]$ & 2.69 & $\mathrm{~B}$ & 1.98 & B & $>3.0$ & - \\
\hline [15] & 3.87 & A & - & - & - & - \\
\hline [13] & - & - & 1.86 & C, D, E & - & - \\
\hline$[25]$ & $>2.2$ & - & 1.75 & B & 2.2 & B \\
\hline [18] & & & & & 3.04 & A \\
\hline ANL\# & 3.15 & A & - & - & 2.56 & A \\
\hline AECL\# & - & - & - & - & 2.72 & - \\
\hline EDF\# & 4.9 & - & - & - & - & - \\
\hline Glasgow\# & - & - & - & - & $2.56-2.82$ & - \\
\hline JAERI\# & - & - & - & - & 3.08 & D \\
\hline JAPC\# & 3.64 & A & - & - & 2.46 & A \\
\hline KINS\# & 3.51 & - & - & - & - & - \\
\hline HSE/NNC\# & 4.49 & - & - & - & - & - \\
\hline NUPEC\# & 4.03 & - & - & - & 2.62 & - \\
\hline IBRAE\# & 3.21 & - & - & - & 2.95 & - \\
\hline PRINCIPIA\# & 3.33 & - & - & - & - & - \\
\hline RINSC\# & 3.85 & - & - & - & - & - \\
\hline SNL/ANATECH\# & 3.38 & B & - & - & - & - \\
\hline
\end{tabular}

A: Cylinder mid-height; B: Equipment hatch; C: Ring beam region; D: Dome; E: Cylinder bottom.

\#: Cite the reference [26].

*: Experimental test. Other predictions used finite element codes.

For clearly reflect the results of related researches about the ultimate pressure and failure mode, a summary was shown in Table 1 [19-26].

\section{Conclusion}

This paper reviewed the studied on internal pressure of prestress concrete containment vessel and discussed the failure mode and ultimate capacity.

\section{Acknowledgement}

This work was financially supported by the PhD Research Startup Foundation of Dalian Ocean University (Grant No. HDYJ201810).

\section{References}

1. Dameron RA, Hansen BE, Parker DR, Rashid YR (2003) Posttest Analysis of the NUPEC/NRC 1:4 Scale Prestressed Concrete Containment Vessel Model. Division of Engineering Technology, Office

of Nuclear Regulatory Research, US Nuclear Regulatory Commission, Washington, USA.

2. Parmar RM, Singh T, Thangamani I, Trivedi N, Singh RK (2014) Overpressure test on BARCOM pre-stressed concrete containment. Nuclear Engineering and Design 269: 177-183.

3. Zhang XB, Lin ST, Chen ZY, Wang YH, Xu HX, et al. (2001) Experimental research on advanced containment model of nuclear power plant. Industrial Construction 31: 33-35.

4. Rizkalla SH, Simmonds SH, MacGregor JG (1984) Prestressed Concrete Containment Model. Journal of Structural Engineering 110(4): 730743.

5. Yonezawa K, Imoto K, Watanabe Y, Akimoto M (2002) Ultimate capacity analysis of $1 / 4$ PCCV model subjected to internal pressure. Nuclear Engineering and Design 212(1): 357-379.

6. Basha SM, Singh RK, Patnaik R, Ramanujam S, Kushwaha HS, et al. (2003) Predictions of ultimate load capacity for pre-stressed concrete containment vessel model with BARC finite element code ULCA. Annals of Nuclear Energy 30(4): 437-471. 


\section{Civil Engineering Research Journal}

7. Prinja NK, Hessheimer MF, Dameron R (2004) Predicting Hoop Tendon Behaviour in Pre-Stressed Concrete Containment Vessel. Applied Mechanics and Materials 1-2: 251-260.

8. Prinja NK, Shepherd D, Curley J (2005) Simulating structural collapse of a PWR containment. Nuclear Engineering and Design 17-19(235): 2033-2043.

9. Lee HP (2011) Shell finite element of reinforced concrete for internal pressure analysis of nuclear containment building. Nuclear Engineering and Design 2(241): 515-525.

10. Kwak HG, Kim JH (2006) Numerical models for prestressing tendons in containment structures", Nuclear Engineering and Design10(236): 1061-1080.

11. Barbat AH, Cervera M, Hanganu A, Cirauqui C, Onate E (1998) Failure pressure evaluation of the containment building of a large dry nuclear power plant. Nuclear Engineering and Design 3(180): 251-270.

12. Zhou Z, Wu C, Meng S-p, Wu J (2014) Mechanical analysis for prestressed concrete containment vessels under loss of coolant accident. Computers and Concrete 14(2): 127-143.

13. Hu HT, Lin YH (2006) Ultimate analysis of PWR prestressed concrete containment subjected to internal pressure. International Journal of Pressure Vessels and Piping 3(83): 161-167.

14. Ghavamian S, Courtois A, Valfort JL (2007) Mechanical simulations of SANDIA II tests OECD ISP 48 benchmark. Nuclear Engineering and Design 13(237): 1406-1418.

15. Noh SH, Moon IH, Lee JB (2007) Analysis of prestressed concrete containment vessel (PCCV) under severe accident loading. Nuclear Engineering and Technology 40: 77-86.

16. Nahas G, Ciree B (2007) Mechanical analysis of the containment building behavior for the French PWR 900 MWe under severe accident. IRSN 19: 1-8.

17. Xia ZF, Wang MD, Huang XL, Wang XW (2002) Design research \& model experiment of containment in 1000MW NPP. Nuclear Power Engineering 23: 123-129.

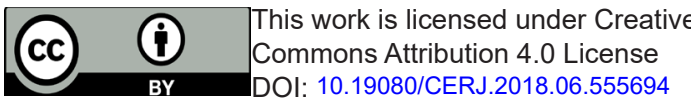

18. Chaobi Z, Jianyun C, Jing L (2007) Ultimate Internal Pressure of Prestressed Concrete Containment Vessel Analyzed by an Integral Constitutive Model. KSCE Journal of Civil Engineering 21(6): 22732280.

19. Wang XW, Wang MD, Xia ZF (2008) Nonlinear Analysis of Ultimate Capacity for Advanced Containment with Hemisphere Dome. Proceedings of the $15^{\text {th }}$ national conference on reactor structural mechanics, pp. 560-566.

20. Wang QK (2014) Study on the Failure Mechanism of Containment for CPR 1000 Nuclear Power Plant. Thesis (master's degree), Dalian University of Technology, China.

21. Chen Q, Qian JR (2002) Nonlinear Finite Element Analysis of 1:10 Containment Model Structure Subjected to Internal Pressure. Engineering Mechanics 19: 73-77.

22. Dameron RA, Rashid YR, Hessheimer MF (2003) Posttest Analysis of a 1:4 Scale Prestressed Concrete Containment Vessel Model. Proceedings of $17^{\text {th }}$ International Conference on Structural Mechanics in Reactor Technology. International Association for Structural Mechanics in Reactor Technology, Prague Czech Republic, pp. 1-8.

23. Zhang HD, Lin ST, Wang YH (2007) Calculation and Analysis of Bearing Capacity of Inner Pressure of Containment Structure in Nuclear Power Plant. Industrial Construction 37: 43-46.

24. Song CN, Hou GL, Zhou LG (2014) Ultimate capacity and influenced factors analysis of nuclear RC containment subjected to internal pressure. Nuclear Science and Engineering 34: 228-235.

25. Cai LJ, Tang Q Meng J (2009) The research of the ultimate bearing capability of prestressed concrete containment of power plant. 2009 Shanghai Forum of Prestressed academic papers, Shanghai, China.

26. Hessheimer MF, Luk VK, Klamerus EW, Shibata S, Mitsug S, et al. (2001) Pretest Round Robin Analysis of 1:4-Scale Prestressed Concrete Containment Vessel Model. Proceedings of the Ninth International Conference on Nuclear Engineering, Nice, France.

\section{Your next submission with Juniper Publishers will reach you the below assets}

- Quality Editorial service

- Swift Peer Review

- Reprints availability

- E-prints Service

- Manuscript Podcast for convenient understanding

- Global attainment for your research

- Manuscript accessibility in different formats

( Pdf, E-pub, Full Text, Audio)

- Unceasing customer service

Track the below URL for one-step submission https://juniperpublishers.com/online-submission.php 